\title{
Dietary requirements of available phosphorus in growing broiler chickens at a constant calcium:available phosphorus ratio
}

\author{
Heloisa Helena de Carvalho Mello, Paulo Cezar Gomes ${ }^{1}$, Horacio Santiago Rostagno', \\ Luiz Fernando Teixeira Albino ${ }^{1}$, Tatiana Cristina da Rocha ${ }^{1}$, Rodrigo Lopes de Almeida ${ }^{1}$, \\ Arele Arlindo Calderano ${ }^{1}$
}

\footnotetext{
${ }^{1}$ Departamento de Zootecnia, Universidade Federal de Viçosa, Viçosa, MG, Brazil.
}

\begin{abstract}
Four experiments were conducted to study the requirements of available phosphorus (aP) for commercial male broilers of 1-10 day of age (exp.1), 11-21 days of age (exp. 2), 22-33 day of age (exp. 3) and 34-46 days of age (exp. 4), at a constant calcium:aP ratio. A complete randomized design was used in each experiment. The experimental diets were fed ad libitum to 8 replicate groups of ten broilers in each. The increments in the levels of aP ranged from 2.0 to $5.5 \mathrm{~g} / \mathrm{kg}$ (exp. 1), 1.9 to $5.4 \mathrm{~g} / \mathrm{kg}$ (exp. 2), 1.8 to $5.3 \mathrm{~g} / \mathrm{kg}$ (exp. 3) and 1.7 to $5.2 \mathrm{~g} / \mathrm{kg}$ (exp. 4), in $0.7 \mathrm{~g} / \mathrm{kg}$. The parameters evaluated were body weight gain, feed intake, feed conversion ratio and bone parameters. The level of aP in the diet influenced the performance of broilers of 1-10 and 11-21 days of age, but did not affect the performance of broilers at 22-33 and 34-46 days of age. Feed intake was not affected. The requirements of $\mathrm{aP}$ and $\mathrm{Ca}$ for male broilers from 1-10, 11-21, 22-33 and 34-46 days of age are 4.82 and $9.64 \mathrm{~g} / \mathrm{kg}, 4.10$ and $8.20 \mathrm{~g} / \mathrm{kg}, 3.95$ and $7.90 \mathrm{~g} / \mathrm{kg}$ and $3.19 \mathrm{~g} . \mathrm{kg}$ and $6.38 \mathrm{~g} / \mathrm{kg}$, respectively. The results indicate that low levels aP were required because the requirements of the mineral reduced as birds aged. Provided there is no excess of dietary levels of $\mathrm{Ca}$, using a $\mathrm{Ca}$ :aP ratio of 2:1 may reduce the dietary levels of aP.
\end{abstract}

Key Words: chicks, diets, mineral, performance, tibia

\section{Introduction}

Phosphorus is an essential mineral for broilers and plays an important role in soft and hard tissues of the body (Underwood \& Suttle, 1999). Phosphorus requirements in poultry are affected by innumerous factors, including the dietary level of calcium (Rama Rao et al., 1999a).

Phytate is the major form of phosphorus storage in plants and its utilization by poultry is highly variable. According to Manangi \& Coon (2008), the utilization of phytate by poultry ranges from 0 to $50 \%$ depending on the age and metabolic adaptation in critical circumstances. Tamim et al. (2004) hypothesized that part of the variation in the extension of hydrolysis of phytate in the small intestine is due to differences in the concentration of calcium in the diets.

Rama Rao et al. (2006) indicated that both calcium and phosphorus co-exist in many biological functions, but the dietary requirement of these minerals is interdependent. Excess of calcium in the diet reduces the absorption of phosphorus due to the formation of insoluble complexes in the intestinal lumen. Moreover, a very low level of calcium is insufficient for bone mineralization, leading to an increase in the excretion of phosphorus. Therefore, instead of only absolute levels, the calcium:phosphorus ratio in diets should be considered.
Previous studies aiming to determine the phosphorus requirement of broilers (Runho et al., 2001; Yan et al., 2001, Yan et al., 2003; Dhandu \& Angel, 2003; Gomes, 2004; Karimi, 2006) used the same calcium:phosphorus ratio for all treatments. Furthermore, the variation in the calcium levels used in most of these experimental diets contributes with variation in the available phosphorus levels recommended.

Rama Rao et al. (2006) reported that tibia ash content was maximal and the phosphorus excretion was minimal when the ratio between the calcium and nonphytin phosphorus was maintained at 2:1 in the diet, regardless of the level of these minerals in diet.

The objective of this study was to determine dietary requirements of available phosphorus at a constant calcium: available phosphours ratio for growing broiler chickens.

\section{Material and Methods}

Four experiments were conducted to determine the requirement of available phosphorus (aP) in commercial male broilers from 1 to $10 ; 11$ to $21 ; 22$ to 33 ; and 34 to 46 days of age. Four hundred and eighty commercial Cobb 500 male broilers were used in each of the four experiments. Experiment 1 was conducted with 1 to 10-day-old 
broilers. Experiment 2 was conducted with 11 to 21-day-old broilers. Experiment 3 was conducted with 22 to 33-day-old broilers. Experiment 4 was conducted with 34 to 46-day-old broilers.

Broilers were randomly assigned in 48 floor pens fitted with a nipple drinker, feeder and infrared lamps for heating the broiler chickens until 14 days of age. The animals were fed standard diets in floor pens prior to the beginning of each experiment. A $5 \mathrm{~cm}$ deep softwood shaving material was used as bedding over a concrete floor. Light was provided for 24 hours daily, using incandescent bulbs. Birds were fed a standard diet. The care and management of the animals followed the recommendations of Cobb Commercial Management Guide (2005).

Corn and soybean meal were analyzed for calcium $(\mathrm{Ca})$ and total phosphorus $(\mathrm{P})$ prior to formulation of experimental diets. The aP content of the feed ingredients was calculated as $33 \%$ of total P (Rostagno et al., 2005). Six diets were formulated with six levels of aP and six levels of $\mathrm{Ca}$ maintaining an identical $\mathrm{Ca}$ :aP ratio $(2: 1)$ in all diets. The levels of aP ranged from 2.0 to $5.5 \mathrm{~g} / \mathrm{kg}$ (exp. 1), 1.9 to $5.4 \mathrm{~g} / \mathrm{kg}$ (exp. 2), 1.8 to $5.3 \mathrm{~g} / \mathrm{kg}$ (exp. 3) and 1.7 to $5.2 \mathrm{~g} / \mathrm{kg}$ (exp. 4), in $0.7 \mathrm{~g} / \mathrm{kg}$ increments.

Corn and soybean meal mash diets were formulated to meet broiler requirements (Rostagno et al., 2005) for all nutrients, except for $\mathrm{Ca}$ and aP (Table 1). The levels of dicalcium phosphate, limestone and inert material (sand) were adjusted to obtain the desired levels of aP and $\mathrm{Ca}$. Metabolizable energy, crude protein and essential digestible amino acid contents were the same for all experimental diets. Each diet was fed to eight replicate groups of 10 animals each. Animals were fed ad libitum and had free access to water throughout the experimental period.

The minimum and maximum temperatures inside the broiler houses were 22 and 31;21 and 29; 19 and 29; and 20 and $28^{\circ} \mathrm{C}$ for experiments $1,2,3$, and 4 , respectively.

At the end of the experiment, the feed intake was measured, and body weight gain and feed conversion ratio were calculated. Three birds per pen were randomly slaughtered by cervical dislocation.

Soft tissue and cartilage caps were trimmed off the left tibia from each animal. Samples were then defatted by Goldfish method for 8 hours using petroleum ether as a solvent. Ash content, levels of calcium and phosphorus of the tibia were analyzed according to methods described by Silva \& Queiroz (2002).

Data were tested by analysis of variance using the software SAEG (Statistical Analysis System, version 9.1). Average observation per pen was used as an experimental
Table 1 - Composition $(\mathrm{g} / \mathrm{kg})$ of basal diets fed to commercial broiler chicks

\begin{tabular}{|c|c|c|c|c|}
\hline Ingredients & Exp.1 & Exp.2 & Exp. 3 & Exp.4 \\
\hline Maize & 522.01 & 539.62 & 569.35 & 611.51 \\
\hline Soybean meal & 397.02 & 378.81 & 339.47 & 297.23 \\
\hline Soybean oil & 29.39 & 34.85 & 44.78 & 44.81 \\
\hline Sodium chloride & 5.15 & 4.93 & 4.71 & 4.43 \\
\hline Choline & 1.00 & 1.00 & 1.00 & 1.00 \\
\hline DL-methionine $99 \%$ & 3.38 & 2.20 & 2.13 & 2.04 \\
\hline L-lysine $\mathrm{HCl} 78 \%$ & 2.69 & 0.86 & 1.13 & 1.69 \\
\hline L-threonine $98 \%$ & 1.11 & 0.05 & 0.11 & 0.32 \\
\hline Antioxidant $^{1}$ & 0.10 & 0.10 & 0.10 & 0.10 \\
\hline Vitamin premix ${ }^{2}$ & 1.00 & 1.00 & 1.00 & 1.00 \\
\hline Trace mineral premix ${ }^{3}$ & 0.50 & 0.50 & 0.50 & 0.50 \\
\hline Coccidiostat $^{4}$ & 0.50 & 0.50 & 0.50 & 0.50 \\
\hline Antimicrobial $^{5}$ & 0.10 & 0.10 & 0.10 & 0 \\
\hline $\mathrm{Ca}$ and $\mathrm{P}$ sources and inert & 36.05 & 35.48 & 35.12 & 34.76 \\
\hline \multicolumn{5}{|l|}{ Calculated nutrient composition } \\
\hline Metabolizable energy $(\mathrm{kcal} / \mathrm{kg})$ & 2,950 & 3,000 & 3,100 & 3,150 \\
\hline Crude protein $(\mathrm{g} / \mathrm{kg})$ & 220.0 & 210.0 & 195.0 & 180.0 \\
\hline Sodium $(\mathrm{g} / \mathrm{kg})$ & 2.23 & 2.14 & 2.05 & 1.94 \\
\hline Digestible lysine $(\mathrm{g} / \mathrm{kg})$ & 13.30 & 11.46 & 10.73 & 10.17 \\
\hline Digestible methionine + cystine $(\mathrm{g} / \mathrm{kg})$ & 9.44 & 8.14 & 7.73 & 7.32 \\
\hline Digestible threonine $(\mathrm{g} / \mathrm{kg})$ & 8.65 & 7.45 & 6.97 & 6.61 \\
\hline Available phosphorus $(\mathrm{g} / \mathrm{kg})$ & 2.0 & 1.9 & 1.8 & 1.7 \\
\hline
\end{tabular}

${ }^{1}$ Butylated hydroxytoluene.

${ }^{2}$ Vitamin premix provided: vit. A - 12,000,000 UI; vit. D3 - 2,200,000 UI; vit. E $30,000 \mathrm{UI}$; vit. B1 - 2,200 mg; vit. B2 - 6,000 mg; vit. B6 - 3,300 mg; pantothenic acid - 13,000 mg; biotin - $110 \mathrm{mg}$; vit. K3 - 2,500 mg; folic acid - 1,000 mg; nicotinic acid -53,000 mg; niacin - 25,000 mg; vit. B12 - 16,000 $\mu \mathrm{g}$; selenium - $0.25 \mathrm{~g}$; antioxidant $-120.000 \mathrm{mg}$.

${ }^{3}$ Trace minerals provided: manganese - 75,000 mg; iron - 20,000 mg; zinc - 50,000 mg; copper - 4,000 mg; iodine - $1,500 \mathrm{mg}$.

${ }^{4}$ Salinomicin $12 \%$

${ }^{5}$ Avilamycin $10 \%$.

unit. The data obtained was subjected to polynomial regression analysis and adjusted by the Linear Response Plateau model. Regression analysis was conducted to estimate aP level for maximum performance and bone mineralization. The model set to explain the data was that which showed the lowest sum of squared deviations and highest correlation coefficient. From the level of aP, the requirement of $\mathrm{Ca}$ was determined as based on the $\mathrm{Ca}: \mathrm{aP}$ ratio of 2:1 (Rostagno et al., 2005).

\section{Results and Discussion}

Body weight gain and feed conversion ratio of commercial broilers from 1-10 days of age improved with increase in the available phosphorus (aP) level up to 4.40 and $4.80 \mathrm{~g} / \mathrm{kg}$ aP, respectively (Table 2, Table 3 ). The ash content and concentration of calcium in the tibia increased with increase in the levels of aP in the diet at 4.82 and $3.90 \mathrm{~g} / \mathrm{kg}$ aP, respectively. A linear increase of $\mathrm{P}$ concentration was observed as the aP levels in the diets increased.

Quadratic effects were observed for body weight gain and feed conversion ratio of broilers from 1 to 10 days of 
age. According to Shafey \& McDonald (1991), the excess dietary calcium $(\mathrm{Ca})$ alone or $\mathrm{Ca}$ and $\mathrm{P}$ together, reduces performance of the chickens and the digestibility of most amino acids. Therefore, higher levels of aP likely decreased the digestibility of amino acids, resulting in depletion of the weight gain of birds.

The aP requirement to improve performance and bone parameters of broiler chickens from 1 to 10 days of age observed in this study were different from previous reports in which the level of aP required to improve bone mineralization was higher than the level of aP required to improve animal performance (Rama Rao et al., 1999b; Waldroup et al., 2000; Yan et al., 2001; Queiroz et al., 2008).

In the current study, variation in the levels of aP did not affect the feed intake. These findings are in disagreement with the previous reports (Runho et al., 2001; Viveros et al., 2002; Queiroz et al., 2008) which suggested that high $\mathrm{Ca}$ aP ratios resulted in lower feed intake. The effect of aP levels on feed intake reported by these authors may be associated with several $\mathrm{Ca}: \mathrm{aP}$ ratios used in experimental diets. Panda et al. (2007) reported that higher Ca:aP ratios resulted in lower serum concentrations of $\mathrm{P}$. These changes in the plasma concentration of $\mathrm{Ca}$ and $\mathrm{P}$ may be responsible for decrease in feed intake. These results corroborate those reported by Lobaugh et al. (1981), who found that $\mathrm{Ca}$ appetite may be inhibited by increased concentrations of ionic $\mathrm{Ca}$ in the blood. The experimental diets used in the present study maintained the $\mathrm{Ca}$ :aP ratio at $2: 1$, which may have contributed to the lack of differences in feed intake.
Body weight gain and feed conversion ratio of 11-21day-old broilers were affected by the levels of aP (Table 4). The predicted aP values for maximum response of the criteria were 3.57 and $3.62 \mathrm{~g} / \mathrm{kg}$ aP, respectively. The tibia ash content increased with the increase in the level of aP up to $4.10 \mathrm{~g} / \mathrm{kg}$ in the diet. A linear effect of increasing dietary aP was observed on $\mathrm{Ca}$ and $\mathrm{P}$ in tibia contents (Table 5). The levels of aP for the highest body weight gain $(3.57 \mathrm{~g} / / \mathrm{kg})$ and the lowest feed conversion ratio $(3.62 \mathrm{~g} / \mathrm{kg})$ of broilers from 11 to 21 days of age were lower than that $(3.91 \mathrm{~g} / \mathrm{kg})$ recommended by Rostagno et al. (2011).

According to Yan et al. (2005), broilers fed a diet moderately deficient in phosphorus and calcium $(3.0 \mathrm{~g} / \mathrm{kg}$ aP and $6.0 \mathrm{~g} / \mathrm{kg} \mathrm{Ca}$ ) from hatching to 18 days of age demonstrated the ability of partially adapting to the deficiency. This ability was achieved by increased ileal absorption of $\mathrm{P}$ and $\mathrm{Ca}$, increased ileal phytate $\mathrm{P}$ disappearance, compensatory growth and compensatory improvement in bone parameters. The application of the adaptation mainly in poultry may enable decreasing $\mathrm{P}$ and $\mathrm{Ca}$ intakes without compromising animal performance.

The predicted aP requirement for broiler chickens from 11 to 21 days of age ranged from 3.62 to $5.4 \mathrm{~g} / \mathrm{kg}$. Waldroup (1999) suggested that in relative terms the requirement of $\mathrm{P}$ be in the following order: bone calcification > body weight $>$ feed efficiency $>$ mortality. In fact, it was found that lower levels of aP were required to improve weight gain and feed conversion ratio rather than to improve bone parameters. However, the use of levels of aP and $\mathrm{Ca}$ in

Table 2 - Effects of aP levels on performance and bone parameters of male broilers (1-10 days of age)

\begin{tabular}{|c|c|c|c|c|c|c|c|c|c|c|}
\hline & \multicolumn{6}{|c|}{ Available phosphorus (g/kg) } & \multirow[b]{2}{*}{ CV (\%) } & \multicolumn{3}{|c|}{ Regression analysis } \\
\hline & 2.0 & 2.7 & 3.4 & 4.1 & 4.8 & 5.5 & & Linear & Quadratic & $\begin{array}{c}\text { Linear Response } \\
\text { Plateau }\end{array}$ \\
\hline Body weight gain (g) & 207.95 & 228.80 & 226.26 & 230.37 & 223.38 & 230.51 & 4.78 & 0.0028 & 0.017 & $>0.05$ \\
\hline Feed intake $(\mathrm{g})$ & 295.96 & 306.80 & 303.07 & 303.18 & 297.99 & 300.25 & 3.71 & 0.883 & 0.186 & $>0.05$ \\
\hline Feed conversion ratio & 1.424 & 1.341 & 1.339 & 1.317 & 1.335 & 1.304 & 3.25 & 0.00002 & 0.021 & $>0.05$ \\
\hline Tibia ash $\left(\mathrm{g} \mathrm{kg}^{-1}\right)$ & 415.3 & 461.1 & 482.9 & 507.6 & 510.6 & 505.7 & 2.74 & 0.0001 & 0.0004 & $<0.01$ \\
\hline $\mathrm{Ca}$ in the tibia $\left(\mathrm{g} \mathrm{kg}^{-1}\right)$ & 145.8 & 154.9 & 167.8 & 175.9 & 171.7 & 177.3 & 3.10 & 0.0001 & 0.0018 & $<0.01$ \\
\hline $\mathrm{P}$ in the tibia $\left(\mathrm{g} \mathrm{kg}^{-1}\right)$ & 82.3 & 87.2 & 91.3 & 96.6 & 102.1 & 104.2 & 3.81 & 0.0001 & 0.855 & $>0.05$ \\
\hline
\end{tabular}

$\mathrm{CV}$ - coefficient of variation.

Table 3 - Requirement of available phosphorus and calcium for male broiler chickens at 1-10 days of age

\begin{tabular}{|c|c|c|c|c|c|c|}
\hline & Model & Equation & $\begin{array}{c}\text { Plateau/max/min. } \\
\text { point }\end{array}$ & $\mathrm{Ca}: \mathrm{aP}$ requirement $(\mathrm{g} / \mathrm{kg})$ & SQD & $\mathrm{R}^{2}$ \\
\hline Body weight gain & Quadratic & $\hat{Y}=169.37+277.19 X-314.82 X^{2}$ & $\hat{\mathrm{Y}}=230.38$ & $8.80: 4.40$ & 133.58 & 0.63 \\
\hline Feed conversion ratio & Quadratic & $\hat{Y}=1.59-1.18 X+1.23 X^{2}$ & $\hat{Y}=1.307$ & $9.60: 4.80$ & 0.00163 & 0.81 \\
\hline \multirow{3}{*}{$\mathrm{Ca}$ in the tibia $\left(\mathrm{g} \mathrm{kg}^{-1}\right)$} & Linear Response Plateau & $\hat{\mathrm{Y}}=48.28+32.27 \mathrm{X}$ & $\hat{\mathrm{Y}}=507.9$ & $7.68: 3.84$ & 0.96 & 0.95 \\
\hline & Quadratic & $\hat{\mathrm{Y}}=9.29+32.30 \mathrm{X}-31.30 \mathrm{X}^{2}$ & $\hat{Y}=176.2$ & $1.032: 5.16$ & 0.369 & 0.95 \\
\hline & Linear Response Plateau & $\hat{Y}=11.36+15.73 X$ & $\hat{\mathrm{Y}}=174.9$ & $7.80: 3.90$ & 0.192 & 0.98 \\
\hline
\end{tabular}

SQD - Sum of square error. 
diets based on optimizing the performance of the birds does not necessarily result in the occurrence of bone problems (Rama Rao et al., 1999b). Further studies on the influence of dietary $\mathrm{P}$ and $\mathrm{Ca}$ on the percentage of bone fractures at processing line are needed to obtain practical data to adjust the levels of these minerals in the diet.

Onyango et al. (2003) found a positive correlation between percentage of ash and shear-force of tibia. According to Driver et al. (2006), the incidence of broken tibias and femurs during processing are affected by levels of $\mathrm{Ca}$ and $\mathrm{P}$ in diet. The authors suggested that feeding $\mathrm{Ca}$ and P-deficient diets affects the integrity of the different bones of the chicken in different ways during slaughter and processing.

The levels of aP did not affect body weight gain, feed intake and feed conversion ratio of broilers from 22-33 days of age (Table 6). The level of Ca in the tibia increased linearly with increase in the levels of dietary aP. The ash and $\mathrm{P}$ contents in the tibia increased until reaching a plateau at 3.95 and $2.66 \mathrm{~g} / \mathrm{kg}$ aP, respectively (Table 7). Increased levels of aP did not affect the performance of broiler chickens from 34-46 days of age (Table 8). The tibia ash content was maximized at $3.19 \mathrm{~g} / \mathrm{kg}$ aP. The dietary levels of aP had a quadratic effect on $\mathrm{P}$ in the tibia content (Table 9).

There was no effect of dietary aP on the performance of broilers from 22 to 33 and 34 to 46 days of age. Previous studies have shown lower aP requirement in the finishing phases. Dhandu \& Angel (2003) reported a requirement of $2.0 \mathrm{~g} / \mathrm{kg}$ aP for male broilers from 22 to 42 days of age based on tibia ash weight. Yan et al. (2003) reported that no more than $1.0 \mathrm{~g} / \mathrm{kg}$ nonphytate phosphorus was sufficient to maximize tibia ash, body weight gain and feed conversion ratio for broilers from 42 to 63 days of age.

Waldroup (1999) suggested that during the later stages of production, when a significant amount of feed is consumed, the requirement of supplemental phosphorus is low when broilers are fed corn-soybean diets. In fact, in this study, broilers from 21-46 days of age had satisfactory growth at the lowest level of phosphorus applied. Since approximately $36 \%$ of the total feed consumed during all period of production is consumed in the last stage of production, considering only performance parameters, the lowest level $(1.7 \mathrm{~g} / \mathrm{kg}$ aP) was sufficient to ensure performance of broilers from 34 to 46 days of age. However, to maintain bone quality, the aP requirement was $3.19 \mathrm{~g} / \mathrm{kg}$.

Broilers fed diets containing $4.40 \mathrm{~g} / \mathrm{kg}$ aP (exp. 1), $3.57 \mathrm{~g} / \mathrm{kg}$ aP (exp. 2), $1.80 \mathrm{~g} / \mathrm{kg}$ aP (exp. 3), and $1.70 \mathrm{~g} / \mathrm{kg} \mathrm{aP}$ (exp. 4) did not increased mortality or leg problems. Thus, the requirement of aP for body weight gain may be taken as the requirement of aP for commercial broilers.

Rama Rao et al. (1999b) reported that high or low dietary phosphorus content may adversely affect bird performance. However, in the current study, when dietary $\mathrm{Ca}$ :aP ratio was 2:1 for 1-21-day-old broilers, an improvement was observed with graded dietary aP. However, no differences in performance of broilers from 22-46 days of age fed low or high aP were observed.

Table 4 - Effects of aP levels on performance and bone parameters of male broilers (11-21 days of age)

\begin{tabular}{|c|c|c|c|c|c|c|c|c|c|c|}
\hline & \multicolumn{6}{|c|}{ Available phosphorus (g/kg) } & \multirow[b]{2}{*}{$\mathrm{CV}(\%)$} & \multicolumn{3}{|c|}{ Regression analysis } \\
\hline & 1.9 & 2.6 & 3.3 & 4.0 & 4.7 & 5.4 & & Linear & Quadratic & $\begin{array}{c}\text { Linear Response } \\
\text { Plateau }\end{array}$ \\
\hline Body weight gain (g) & 465.75 & 484.58 & 517.22 & 527.09 & 514.71 & 532.21 & 4.17 & 0.0001 & 0.009 & $<0.01$ \\
\hline Feed intake $(\mathrm{g})$ & 767.75 & 789.565 & 799.88 & 807.69 & 801.81 & 803.56 & 3.93 & 0.202 & 0.111 & $>0.05$ \\
\hline Feed conversion ratio & 1.650 & 1.629 & 1.547 & 1.533 & 1.559 & 1.510 & 3.14 & 0.0001 & 0.0746 & $>0.05$ \\
\hline Tibia ash $\left(\mathrm{g} \mathrm{kg}^{-1}\right)$ & 488.0 & 500.7 & 518.3 & 535.6 & 531.5 & 537.5 & 1.20 & 0.00001 & 0.0005 & $<0.01$ \\
\hline $\mathrm{Ca}$ in the tibia $\left(\mathrm{g} \mathrm{kg}^{-1}\right)$ & 168.0 & 160.1 & 169.9 & 169.4 & 174.9 & 180.5 & 2.86 & 0.00006 & 0.037 & $>0.05$ \\
\hline $\mathrm{P}$ in the tibia $\left(\mathrm{g} \mathrm{kg}^{-1}\right)$ & 89.2 & 88.7 & 88.5 & 90.1 & 90.4 & 93.2 & 2.47 & 0.011 & 0.086 & $>0.05$ \\
\hline
\end{tabular}

$\mathrm{CV}$ - coefficient of variation.

Table 5 - Requirement of available phosphorus and calcium for male broiler chickens at 11-21 days of age

\begin{tabular}{|c|c|c|c|c|c|c|}
\hline & Model & Equation & $\begin{array}{l}\text { Plateau/max/min. } \\
\text { point }\end{array}$ & $\mathrm{Ca}: \mathrm{aP}$ requirement $(\mathrm{g} / \mathrm{kg})$ & SQD & $\mathrm{R}^{2}$ \\
\hline \multirow[t]{2}{*}{ Body weight gain } & Quadratic & $\hat{\mathrm{Y}}=371.74+672.33 \mathrm{X}-679.30 \mathrm{X}^{2}$ & $\hat{Y}=538.10$ & $9.90: 4.95$ & 319.29 & 0.90 \\
\hline & Linear Response Plateau & $\hat{Y}=393.72+367.21 X$ & $\hat{Y}=524.67$ & $7.14: 3.57$ & 194.01 & 0.97 \\
\hline \multirow[t]{2}{*}{ Tibia ash $\left(\mathrm{g} \mathrm{kg}^{-1}\right)$} & Quadratic & $\hat{Y}=41.31+46.63 X-43.88 X^{2}$ & $\hat{Y}=53.70$ & $10.62: 5.31$ & 0.74 & 0.96 \\
\hline & Linear Response Plateau & $\hat{Y}=44.59+21.68 X$ & $\hat{Y}=53.48$ & $8.20: 4.10$ & 0.22 & 0.99 \\
\hline $\mathrm{Ca}$ in the tibia $\left(\mathrm{g} \mathrm{kg}^{-1}\right)$ & Linear & $\hat{\mathrm{Y}}=15.46+4.34 \mathrm{X}$ & & $\geq 10.8: 5.4$ & 0.73 & 0.68 \\
\hline
\end{tabular}


The results of this study confirm that the available phosphorus requirement of broilers was reduced, which might be done by adjusting the levels of dietary calcium. These data show the trend of reduced levels of available phosphorus recommended by Rostagno et al. (2011), compared with Rostagno et al. (2005), contributing to reduce the production costs.

There was a reduction in the requirements of aP as the age of the animals increased. Therefore, using a Ca:aP ratio equal to $2: 1$, the aP requirement may be reduced as long as there is no excess of dietary levels of $\mathrm{Ca}$.

Broilers require high levels of available phosphorus at the starter phase. However, during the growth and fininishing phases, this amount may be reduced. At the starter phase of rearing (1-10 days of age), a high level of phosphorus is required to maximize bone parameters. The use of Ca:aP ratio at 2:1 led to a reduction of dietary levels of phosphorus without compromising the performance and mortality of birds.

Table 6 - Effects of aP levels on performance and bone parameters of male broilers (22-33 days of age)

\begin{tabular}{|c|c|c|c|c|c|c|c|c|c|c|}
\hline & \multicolumn{6}{|c|}{ Available phosphorus (g/kg) } & \multirow[b]{2}{*}{$\mathrm{CV}(\%)$} & \multicolumn{3}{|c|}{ Regression analysis } \\
\hline & 1.8 & 2.5 & 3.2 & 3.9 & 4.6 & 5.3 & & Linear & Quadratic & $\begin{array}{c}\text { Linear Response } \\
\text { Plateau }\end{array}$ \\
\hline Body weight gain (g) & 906.63 & 899.71 & 935.92 & 910.28 & 894.52 & 949.70 & 4.03 & 0.1189 & 0.397 & $>0.05$ \\
\hline Feed intake(g) & 1542 & 1513 & 1514 & 1513 & 1488 & 1570 & 2.76 & 0.623 & 0.126 & $>0.05$ \\
\hline Feed conversion ratio & 1.704 & 1.684 & 1.617 & 1.664 & 1.666 & 1.652 & 3.07 & 0.0880 & 0.0698 & $>0.05$ \\
\hline Tibia ash $\left(\mathrm{g} \mathrm{kg}^{-1}\right)$ & 494.5 & 497.7 & 509.5 & 512.1 & 517.8 & 512.8 & 1.68 & 0.0004 & 0.1138 & $<0.05$ \\
\hline $\mathrm{Ca}$ in the tibia $\left(\mathrm{g} \mathrm{kg}^{-1}\right)$ & 165.7 & 172.3 & 171.0 & 170.3 & 176.2 & 177.8 & 3.01 & 0.0040 & 0.881 & $>0.05$ \\
\hline$P$ in the tibia $\left(\mathrm{g} \mathrm{kg}^{-1}\right)$ & 75.9 & 84.3 & 87.5 & 83.2 & 84.5 & 84.0 & 5.15 & 0.0533 & 0.01562 & $<0.05$ \\
\hline
\end{tabular}

$\mathrm{CV}$ - coefficient of variation.

Table 7 - Requirement of available phosphorus and calcium for male broiler chickens at 22-33 days of age

\begin{tabular}{|c|c|c|c|c|c|c|}
\hline & Model & Equation & $\begin{array}{c}\text { Plateau/max/min. } \\
\text { point }\end{array}$ & $\mathrm{Ca}: \mathrm{aP}$ requirement $(\mathrm{g} / \mathrm{kg})$ & SQD & $\mathrm{R}^{2}$ \\
\hline \multirow[t]{2}{*}{ Tibia ash $(\mathrm{g} / \mathrm{kg})$} & Quadratic & $\hat{Y}=45.84+23.18 X-23.77 X^{2}$ & $\hat{\mathrm{Y}}=51.49$ & $9.76: 4.88$ & 0.3301 & 0.92 \\
\hline & Linear Response Plateau & $\hat{\mathrm{Y}}=47.84+8.70 \mathrm{X}$ & $\hat{\mathrm{Y}}=51.28$ & $7.9: 3.95$ & 0.1737 & 0.95 \\
\hline \multirow[t]{2}{*}{$\mathrm{P}$ in the tibia $(\mathrm{g} / \mathrm{kg})$} & Quadratic & $\hat{\mathrm{Y}}=5.64+15.10 \mathrm{X}-19.14 \mathrm{X}^{2}$ & $\hat{\mathrm{Y}}=8.62$ & $7.88: 3.94$ & 0.2348 & 0.69 \\
\hline & Linear Response Plateau & $\hat{\mathrm{Y}}=6.17+8.31 \mathrm{X}$ & $\hat{\mathrm{Y}}=8.39$ & $5.32: 2.66$ & 0.0551 & 0.93 \\
\hline
\end{tabular}

SQD - Sum of square error

Table 8 - Effects of aP levels on performance and bone parameters of male broilers (34-46 days of age)

\begin{tabular}{|c|c|c|c|c|c|c|c|c|c|c|}
\hline & \multicolumn{6}{|c|}{ Available phosphorus (g/kg) } & \multirow[b]{2}{*}{$\mathrm{CV}(\%)$} & \multicolumn{3}{|c|}{ Regression analysis } \\
\hline & 1.7 & 2.4 & 3.1 & 3.8 & 4.5 & 5.2 & & Linear & Quadratic & $\begin{array}{c}\text { Linear Response } \\
\text { Plateau }\end{array}$ \\
\hline Body weight gain (g) & 878.58 & 898.27 & 931.50 & 895.12 & 848.96 & 895.88 & 4.96 & 0.459 & 0.21301 & $>0.05$ \\
\hline Feed intake $(\mathrm{g})$ & 2036 & 2022 & 2182 & 2092 & 2069 & 2058 & 3.93 & 0.511 & 0.715 & $>0.05$ \\
\hline Feed conversion ratio & 2.320 & 2.256 & 2.342 & 2.342 & 2.440 & 2.299 & 3.97 & 0.1111 & 0.2729 & $>0.05$ \\
\hline Tibia ash $\left(\mathrm{g} \mathrm{kg}^{-1}\right)$ & 502.8 & 513.3 & 523.0 & 525.4 & 524.5 & 523.2 & 1.17 & 0.00004 & 0.00192 & $<0.01$ \\
\hline $\mathrm{Ca}$ in the tibia $\left(\mathrm{g} \mathrm{kg}^{-1}\right)$ & 188.5 & 189.1 & 182.8 & 193.0 & 183.8 & 180.1 & 2.74 & 0.03881 & 0.17316 & $>0.05$ \\
\hline $\mathrm{P}$ in the tibia $\left(\mathrm{g} \mathrm{kg}^{-1}\right)$ & 88.7 & 91.9 & 90.0 & 89.6 & 84.9 & 80.3 & 2.32 & 0.00001 & 0.00002 & $>0.05$ \\
\hline
\end{tabular}

$\mathrm{CV}$ - coefficient of variation.

Table 9 - Requirement of available phosphorus and calcium for male broiler chickens at 34 to 46 days of age

\begin{tabular}{|c|c|c|c|c|c|c|}
\hline & Model & Equation & $\begin{array}{c}\text { Plateau/max } / \mathrm{min} . \\
\text { point }\end{array}$ & $\mathrm{Ca}: \mathrm{aP}$ requirement $(\mathrm{g} / \mathrm{kg})$ & SQD & $\mathrm{R}^{2}$ \\
\hline \multirow[t]{2}{*}{ Tibia ash $(\mathrm{g} / \mathrm{kg})$} & Quadratic & $\hat{Y}=46.06+31.07 X-36.89 X^{2}$ & $\hat{Y}=52.60$ & $8.42: 4.21$ & 0.045 & 0.98 \\
\hline & Linear Response Plateau & $\hat{\mathrm{Y}}=47.85+14.38 \mathrm{X}$ & $\hat{Y}=52.43$ & $6.38: 3.19$ & 0.025 & 0.99 \\
\hline
\end{tabular}

SQD - Sum of square error 


\section{Conclusions}

For male broiler chicks from 1 to $10 ; 11$ to $21 ; 22$ to 33 ; and 34 to 46 days of age, the dietary levels of available phosphorus and calcium recommended are 4.82 and 9.64; 4.10 and $8.20 ; 3.95$ and 7.90 ; and 3.19 and $6.38 \mathrm{~g} / \mathrm{kg}$, respectively, corresponding to an aP and $\mathrm{Ca}$ intake of 6.29 and $12.58 ; 6.21$ and $12.42 ; 6.57$ and $13.14 ; 7.44$ and $14.88 \mathrm{mg} / \mathrm{g}$ weight gain.

\section{Acknowledgments}

The authors wish to express their gratitude to Universidade Federal de Viçosa and to CNPq (Conselho Nacional de Desenvolvimento Científico e Tecnológico).

\section{References}

COBB broiler management guide. S.I.: s.n., 2005. 58p.

DHANDU, A.S.;ANGEL, R. Broiler nonphytin phosphorus requirement in the finisher and withdrawal phases of a commercial four-phase feeding system. Poultry Science, v.82, p.1257-1265, 2003.

DRIVER, J.P.; PESTI, G.M.; BAKALLI, R.I. et al. The effect of feeding calcium- and phosphorus-deficient diets to broiler chickens during the starting and growing-finishing phases on carcass quality. Poultry Science, v.85, p.1939-1946, 2006.

GOMES, P.C.; RUNHO, R.C.; D'AGOSTINI, P. et al. Exigência de fósforo disponível para frangos de corte machos e fêmeas de 22 a 42 e de 43 a 53 dias de idade. Revista Brasileira de Zootecnia, v.33, p.1734-1746, 2004 (supl. 1).

KARIMI, A. Responses of broiler chicks to non-phytate phosphorous levels and phytase supplementation. International Journal of Poultry Science, v.5, p.251-254, 2006.

LOBAUGH. B.; JOSHUA. I.G.; MUELLER. W.J. Regulation of calcium appetite in broiler chickens. The Journal of Nutrition, v.111, p.298-306, 1981.

MANANGI, M.K.; COON, C.N. Phytate phosphorus hydrolysis in broilers in response to dietary phytase. calcium. and phosphorus concentrations. Poultry Science, v.87, p.1577-1586, 2008.

ONYANGO, E.M.; HESTER, P.Y.; STROSHINE, R. et al. Bone densitometry as an indicator of percentage tibia ash in broiler chicks fed varying dietary calcium and phosphorus levels. Poultry Science, v.8, p.1787-1791, 2003.

PANDA, A.K.; RAMA RAO, S.V.; RAJU, M.V.L.N. et al. Performance of broiler chickens fed low non phytate phosphorus diets supplemented with microbial phytase. The Journal of Poultry Science, v.44, p.258-264, 2007.

PERSIA, M.E.; SAYLOR, W.W. Effects of broiler strain. dietary nonphytate phosphorus. and phytase supplementation on chick performance and tibia ash. Journal Applied Poultry Research, v. 15, p.72-81, 2006.
QUEIROZ, L.S.; BERTECHINI, A.G.; RODRIGUES, P.B. et al. Utilização de fosfatos comerciais para frangos de corte na fase inicial. Pesquisa Agropecuária Brasileira, v.43, p.1421-1427, 2008.

RAMA RAO, S.V.; RAVINDRA REDDY, V.; RAMASUBBA REDDY, V. Enhancement of phytate phosphorus availability in the diets of commercial broilers and layers. Animal Feed Science and Technology, v.79, p.211-222, 1999a.

RAMA RAO, S.V.; RAMASUBBA REDDY, V.; RAVINDRA REDDY, V. Non-phytin phosphorus requirements of commercial broilers and White Leghorn layers. Animal Feed Science and Technology, v.80, p.1-10, 1999b.

RAMA RAO, S.V.; RAJU, M.V.L.N.; REDDY, M.R. et al. Interaction between dietary calcium and non-phytate phosphorus levels on growth. bone mineralization and mineral excretion in commercial broilers. Animal Feed Science and Technology, v.131, p.133-148, 2006.

ROSTAGNO, H.S.; ALBINO, L.F.T.; DONZELE, J.L. et al. Tabelas brasileiras para aves e suínos: composição de alimentos e exigências nutricionais. 2.ed. Viçosa, MG: UFV. 2005. 186p.

ROSTAGNO, H.S.; ALBINO, L.F.T.; DONZELE, J.L. et al. Tabelas brasileiras para aves e suínos: composição de alimentos e exigências nutricionais. 3.ed. Viçosa, MG: UFV. 2011. 252p.

RUNHO, R.C.; GOMES, P.C.; ROSTAGNO, H.S. et al. Exigência de fósforo disponível para frangos de corte machos e fêmeas de 1 a 21 dias de idade. Revista Brasileira de Zootecnia, v.30, p.187-196, 2001.

SHAFEY, T.M.; MCDONALD, M.W. The effects of dietary concentrations of minerals. source of protein. amino acids and antibiotics on the growth of and digestibility of amino acids by broiler chickens. British Poultry Science, v.32, p.535-44, 1991.

SILVA, D.J.; QUEIROZ, A.C. Análise de alimentos (métodos químicos e biológicos). 3.ed. Viçosa, MG: UFV, 2002. 235p.

TAMIM. N.M.; ANGEL. R.; CHRISTMAN. M. Influence of dietary calcium and phytase on phytate phosphorus hydrolysis in broiler chickens. Poultry Science, v.83, p.1358-1367, 2004.

UNDERWOOD, E.J.; SUTTLE. N.F. The mineral nutrition of livestock. 3.ed. Wallingford: CABI Publication, 1999. 614p.

VIVEROS, A.; BRENES, A.; ARIJA, I. Effects of microbial phytase supplementation on mineral utilization and serum enzyme activities in broiler chicks fed different levels of phosphorus. Poultry Science, v.81, p.1172-1183, 2002.

WALDROUP, P.W. Nutritional approaches to reducing phosphorus excretion by poultry. Poultry Science, v.78, p.683-691, 1999.

WALDROUP, P.W.; KERSEY, J.H.; SALEH, E.A. et al. Nonphytate phosphorus requirement and phosphorus excretion of broiler chicks fed diets composed of normal or high available phosphate maize with and without microbial phytase. Poultry Science, v.79, p.1451-1459, 2000.

YAN, F.; KERSEY, J.H.; WALDROUP, P.W. Phosphorus requirements of broiler chicks three to six weeks of age as influenced by phytase supplementation. Poultry Science, v.80, p.455-459, 2001.

YAN, F.; KERSEY, J.H.; FRITTS, C.A. et al. Phosphorus requirements of broiler chicks six to nine weeks of age as influenced by phytase supplementation. Poultry Science, v.82, p.294-300, 2003.

YAN, F.; ANGEL, R.; ASHWELL, C. et al. Evaluation of the broiler's ability to adapt to an early moderate deficiency of phosphorus and calcium. Poultry Science, v.84, p.1232-1241, 2005. 